\title{
The Development of Story-Telling Ability for Early Childhood Through Wayang Game
}

\author{
Yulsyofriend \\ Department of Early Childhood Education \\ Faculty of Education, UniversitasNegeri Padang \\ Padang, Indonesia \\ yenpgpaudfipunp@gmail.com
}

\begin{abstract}
The ability of story telling in early childhood is very important to be developed because the language can help in shaping the mindset of children. In order to develop the language aspect the teacher can use the storytelling method to tell something about the actual, imaginary, action or events that are going on around him. In this case, early childhood is expected to be able for tell his story well from his own experience and retell the story an easily understandable sequence also can stimulate the child to express his opinion based on the story that has been heard. In addition to using the method of storytelling, a teacher can use a variety of media game. One of them is Wayang. Storytelling with Wayang Game will make the children look enthusiastic and energetic to listen because telling them a story by Wayang is an interesting and new thing for them.
\end{abstract}

Keywords-- wayang game; early childhood; storytelling.

\section{INTRODUCTION}

One aspect of development that should be stimulated in early childhood is the ability of the child's language.Language ability is the ability of children to listen and speak. The ability of speaking and learning in early childhood is very important to be developed because the language can help in shaping the mindset of children, because by communicating the child can pour his thoughts into the language according to the language itself. Language development of children can encourage the development of children's thinking skills, because the language of children can communicate with the people around him and children can recognize the various objects around him better. Thus they can gain a faster experience from their environment.

Developing a child's language can use a variety of methods, one method used is the method of storytelling by using media. Storytelling is a very productive language skills[1]. Young children love stories. Stories teach themmany concepts about life. Because by telling a story people can engage his thoughts in pouring his thoughts, mental readiness, courage, clear words so that can be understood by others.Kilpatrick, Wolfe, \& Wolfe [2] arguedthat the characters in a story help children tounderstand problems in different perspectives; toencourage children to share; and build a sense ofempathy. Storytelling is a perfect way to teachchildren to think critically, realistically, but alsoimaginatively.

\section{THEORETICAL BACKGROUND}

\section{A. Development of Early Childhood Storytelling}

According to Yamin and Sanan[3] language is a communication tool used through the sound system, words, patterns that humans use to convey the exchange of thoughts and feelings. According to Susanto[4]language is a tool to think, express yourself and communicate. Language skills are also important in the framework of concept formation, information and problem solving. Through language we can understand the communication of thoughts and feelings.

Story is a description of a particular event.Storytelling is said as telling, that is to convey a picture or description of a particular event. That is, telling is an activity to describe the experience or events that have been experienced[5]. According to Hidayat in Rahayu[6], storytelling is an activity tell something that tells about the actions, experiences, or events that really happened or the results of fiction.Heroman and Jones in Rahayu[6] suggests that storytelling is one of the oldest art, form of entertainment, and the oldest superstition that has been trusted in value from generation to generation. Meanwhile, according to Larkin in Rahayu[6] states storytelling is the art of conversing verbally.Storytelling is different from reading a story (storyreading), storytelling is telling a story without the help of books, pictures or other props that could break the magnetic flux between the listener and the storyteller.[7]

\section{B. The Benefits of Storytelling}

Rahayu [3] suggests the benefits of storytelling activities is that children can develop vocabulary, speaking skills, express stories conveyed in accordance with the characteristics of the characters told in a fun situation for children and can train the courage of children to appear in public. 


\section{Storytelling Strategy}

Octavyani[8] suggests several strategies to make the story more interesting: 1) use interesting and age-appropriate language, 2) tell the story while showing the sections to tell, 3) express his or her opinion, 4) give the child a chance to enter the story, 5) insert advice or moral message in the story, 6) ask the child to reveal what he knows from the story, 7) occasionally sing songs related to the story.

The world of the child is a world of play, in his life the child needs considerable time to develop himself through play. Likewise with storytelling, is also done through play activities using a variety of media. According to Gerlach and Elly in Kustandi, et.al [9] states that the media when understood in broad outline is human, material, or events that build conditions that make early childhood able to acquire knowledge, skill or attitude.

\section{Concept of Wayang}

Playing has a positive role for the development of the child. One form of playing activities in kindergarten is through games, including traditional games. There are various implementations of traditional playing activities and games conducted in the school including through the development of learning model based on the culture of national character and play $(\mathrm{BKKB})[10]$. Wayang is one of the most elaborate and delicate forms of drama or theater, which is continuously developed from one generation to the next. Wayang is a form of performing arts in the form of a distinctive drama which includes sound art, literary arts, music art, speech art, painting and others into a beautiful unity. According to Abimanyu in Utami[11]Wayang is a decorative that is an expression of national culture and is also a medium of education, media information and entertainment media. However, Wayanggolek as one of the traditional culture from West Java is dolls of wood and shaped humanlike [12]

\section{E. The Purpose of Storytelling with Wayang}

According to Anafi[13] the purpose of telling stories with wayang is as follows: a). To facilitate the child in finding the idea of the story he wanted to tell. b). To stimulate the imagination and creativity of children in telling stories. c). Establish an atmosphere of learning becomes more fun and can foster interest, motivation, courage and activeness of children in following the activities of story telling. d). Can be used as a medium of learning and educational and playful games for children.

\section{F. The Benefits of Storytelling with Wayang}

According to Madyawati [14] Some of the benefits of telling stories with wayangkardus for early childhood: 1). Train the children's absorption; 2). Train the concentration of the child to focus his attention on the whole story. 3). Create an exciting situation and develop an intimate relationship. 4). Train the child's mind; and 5). developing children's imagination helps the development of the child's language.

\section{G. Excess Story with Media Puppet}

According to Utami[11]the advantages of telling stories using puppets, among others: 1). Can train children's mind and fantasy; 2). Create a fun atmosphere for children; 3). Develop language skills and increase the vocabulary of the child; 4). Can also be used to preserve the culture of performing arts because of historical value, and 5). The time spent telling stories is more effective and efficient.

According Madyawati[14]excess storytelling by using the puppet as follows: 1). train children's absorption. 2). Train the concentration of children to focus on the whole story. 3). Creating an exciting sutuasi and developing an intimate relationship. 4). Training the child's mind. 5). Developing children's imagination; and 6). Helps child language development.

\section{H. Steps Telling Story with Wayang}

The way of storytelling with wayang according to Rahayu[6] is as follows: 1). The teacher issues the media to be used in the activity; 2). The teacher asks the child to cut out the colored pictures; 3 ). Teacher asks the child to put an ice cream stick behind the picture; 4). The teacher explains and tells the child about the theme and the title of the story; 5). The teacher tells the story to the child, after which the teacher asks each child to play the character in wayang-wayangan. 6). Teachers motivate children to want to tell stories. 7). After completing the story tell the teacher and the child do Questions and answers about stories that have been told by the teacher.

\section{DISCUSSION}

Language is one communication tool for everyone. One aspect of language skills that must be developed in children is the ability to tell stories. Through story telling children will be able to express what he feels and through storytelling will also foster a bold attitude on children, where children dare to express their opinions to others.

To develop the ability to tell the story of the child needed some effort that is by using media or game that interesting and fun for child, one of them is by Wayang Media, In this case Utami[11] expresses advantages of telling story using wayang, 1) Can train children's mind and fantasy, 2) Create a fun atmosphere for children, 3) Develop language skills and increase the vocabulary of children, 4) Can also be used to preserve the culture of performing arts because of historical value, 5) Time spent on tells the story more effectively and efficiently.

According to Madyawati[14] the advantages of telling the story by using the puppets as follows: 1) To train children's absorption, 2) To train the concentration of children to concentrate on the whole story, 3) Creating an exciting sutuasi and developing the atmosphere intimate relationships, 4) Train the minds of children, 5) Developing imagination of children, 6) Helping the development of children's language.

Storytelling with children's play puppet show is enthusiastic to listen to the teacher telling stories and express their opinion, 
because storytelling by using this puppet is an interesting and new thing for them.

\section{References}

[1] Rahiem, Maila Dinia Husni, et.al. "Al Kindergarten Teachers and Moral Education for young children; why do narratives matter?," vol. 58, pp. 301-305, 2017.

[2] S. M. Kilpatrick, W., Wolfe, G., \& Wolfe, Moral, Books that Build Character: A Guide to Teaching Your Child. New York: Touchstone, 1994.

[3] M. dan J. S. S. Yamin, Panduan PAUD Pendidikan Anak Usia Dini. Jakarta: Gaung Persada Press Group.

[4] A. . Susanto, Perkembangan Anak Usia Dini Pengantar Dalam Berbagai Aspeknya. Jakarta: Kencana., 2011.

[5] R. Wulandari, "Pengaruh Penggunaan Media Wayang Terhadap Keterampilan Menyimak Cerita Siswa Kelas II B SD Negeri Kasongan Bantul," Univ. Negeri Yogyakarta., 2015.

[6] A. Rahayu, Menumbuhkan Kepercayaan Diri Melalui Kegiatan Bercerita. Jakarta: PT. Indeks, 2013.

[7] D. Kusumawati and Y. Rachmawati, "Optimizing Storytelling through Dual Coding Theory," Proc. 3Rd Int. Conf. Early Child. Educ. (Icece 2016), vol. 58, pp. 131-135, 2016.

[8] V. Octavyani, Asyiknya Mendongeng dengan Boneka Jari. Jakarta: Demedia Pustaka., 2011.

[9] B. Kustandi, Cecep dan Sutjipto, Media Pembelajaran Manual dan Digital. Bogor: Ghalia Indonesia. 2011.

[10] E. Kurniati, I. N. Kamila, and C. Eliyawati, "Playing and Traditional Games in Learning Model Based on Culture of National Character and Play," vol. 58, pp. 187-192, 2017.

[11] T. Utami, "Upaya Meningkatkan Kepercayaan Diri Dengan Metode Bercerita Menggunakan Wayang Kardus Pada Anak.,” 2014.

[12] Wikipedia., "Wayang golek. (Online).," 2016. [Online]. Available: https://id.wikipedia.org/wiki/Wayang_golek.

[13] Anafi., "Peningkatan Keterampilan Bercerita dengan Menggunakan Media Wayang Boneka pada Siswa Kelas Vii B SMP Negeri 1 Seyegan Sleman .,"Univ. Negeri Yogyakarta, 2012.

[14] L. Madyawati, Strategi Pengembangan Bahasa pada Anak. Jakarta: Kencana. 